\title{
Bronchodilator effect of deep inspiration and bronchoconstriction-triggered cough
} Noriyuki Ohkura*, Masaki Fujimura, Akira Tokuda, Johsuke Hara, Akihiro Hori, Masaru Nishitsuji, Miki Abo and Nobuyuki Katayama

Address: Respiratory Medicine, Cellular Transplantation Biology, Kanazawa, University Graduate School of Medical Science, Japan

Email: Noriyuki Ohkura* - nori@med3.m.kanazawa-u.ac.jp; Masaki Fujimura - fujimura@med3.m.kanazawa-u.ac.jp; Akira Tokuda - tokuda@med3.m.kanazawa-u.ac.jp; Johsuke Hara - hara@ipch.jp; Akihiro Hori - hori@med3.m.kanazawa-u.ac.jp; Masaru Nishitsuji - nishitsuji@med3.m.kanazawa-u.ac.jp; Miki Abo - abo@med3.m.kanazawa-u.ac.jp;

Nobuyuki Katayama - katayama@med3.m.kanazawa-u.ac.jp

* Corresponding author

Published: 20 November 2009

Cough 2009, 5:9 doi:10.1186/1745-9974-5-9

This article is available from: http://www.coughjournal.com/content/5/I/9

(C) 2009 Ohkura et al; licensee BioMed Central Ltd.

This is an Open Access article distributed under the terms of the Creative Commons Attribution License (http://creativecommons.org/licenses/by/2.0), which permits unrestricted use, distribution, and reproduction in any medium, provided the original work is properly cited.

\begin{abstract}
Background: Cough in the patients with cough variant asthma is triggered by bronchoconstriction, which responds to bronchodilator therapy. Following airway narrowing induced by inhaled methacholine, deep inspiration (DI) causes dilation of the airways in both asthmatic and non-asthmatic subjects. The aim of the present study was to investigate the relationship between bronchodilator effect of $\mathrm{DI}$ and bronchoconstriction-triggered cough.
\end{abstract}

Methods: We measured airway responsiveness to methacholine using partial and full flow-volume curves in 28 healthy adults. The expiratory flow at $40 \%$ above residual volume from the full forced vital capacity $\left(\mathrm{MEF}_{40}\right)$ was obtained and the volume was used as the reference volume to determine the isovolume flow from the partial curve $\left(\mathrm{PEF}_{40}\right)$. Coughs were counted for $32 \mathrm{~min}$ during and following the inhalation of methacholine at the provocative concentration which produced a $20 \%$ fall or more in $\mathrm{FEV}_{1}$ from the post-saline value $\left(\mathrm{PC}_{20}-\mathrm{FEV}_{1}\right)$. The bronchodilator effect of $\mathrm{DI}$ on bronchoconstriction induced by methacholine at the $\mathrm{PC}_{20}-\mathrm{FEV}$, concentration was expressed as the ratio of $\left(\mathrm{MEF}_{40}-\mathrm{PEF}_{40}\right) / \mathrm{PEF}_{40}$ (DI index).

Results: The number of coughs for 32 min during and following the inhalation of $\mathrm{PC}_{20}-\mathrm{FEV}_{\text {, }}$ concentration of methacholine was $39.3 \pm 29.7$ (mean \pm SD)/32 min. The number of coughs during and following the inhalation was correlated with $\mathrm{DI}$ index $(r=0.57, \mathrm{p}=0.0015)$, but not with $\mathrm{PC}_{20^{-}}$ $F E V_{1}$ or change in $\mathrm{FEV}_{1}$ or $\mathrm{PEF}_{40}$ by inhalation of the $\mathrm{PC}_{20}-\mathrm{FEV}_{1}$ concentration of methacholine.

Conclusion: We found that methacholine-induced cough was associated with the bronchodilator effect of DI on methacholine induced-bronchoconstriction in normal subjects.

\section{Introduction}

Cough is a common and distressing symptom. Eosinophilic airway disorders such as bronchial asthma (BA), cough variant asthma (CVA) [1], eosinophilic bronchitis without asthma [2], and atopic cough (AC) [3] are important causes of chronic non-productive cough. As the mechanism of cough, at least the following two are considered: one is a cough caused by cough reflex hypersensi- 
tivity that is relevant to $\mathrm{AC}$, gastroesophageal reflux disease (GERD) [4] and angiotensin-converting enzyme inhibitor-induced cough [5]. Another is a cough triggered by bronchoconstriction in such as CVA and BA, which responds to bronchodilator therapy $[1,6]$.

Capsaicin has achieved widespread use for measurement of cough reflex sensitivity [7]. Several studies suggest that capsaicin-induced cough is mediated by the selective excitation of C-fiber receptors, which have thin non-myelinated vagal afferents, and by the subsequent release of tachykinins. Recently, the C-fiber receptor for capsaicin has been identified as transient receptor potential vanilloid 1 (TRPV1), which is expressed in guinea pigs. TRPV1 mediates cough induced by capsaicin [8]. An increased expression of TRPV1 has also been reported in humans with chronic cough [9]. On the other hand, the mechanism of cough triggered by bronchoconstriction is not clear yet. It has been reported that cough sensitivity to capsaicin or mannitol does not directly correlate to bronchoconstriction in normal and asthmatic subjects [10-12]. Inhalation of methacholine produces bronchoconstriction, and methacholine challenge test is usually done for evaluating bronchial hyperresponsiveness (BHR) [13]. There are few reports concerning cough induced by methacholine inhalation in human, because it is known that methacholine is a bronchoconstrictor, but not an efficacious cough inducer [14].

It is well recognized that the response of the airways to deep inspiration (DI) differs between asthmatic and nonasthmatic subjects. Following airway narrowing induced by inhaled methacholine, DI causes dilation of the airways in both asthmatic and nonasthmatic subjects [15]. However, the magnitude of the bronchodilating effect is usually less in asthmatic than in nonasthmatic subjects. It has been suggested that the inability of DI to overcome bronchoconstriction is a fundamental abnormality of asthma, and could contribute to BHR [15].

The aim of the present study was to investigate the correlation of cough triggered by methacholine-induced bron- choconstriction to airway smooth muscle (ASM) tone and bronchodilating effect of DI on methacholine-induced bronchoconstriction in normal subjects.

\section{Materials and methods Subjects}

Twenty-eight normal subjects [2 men and 26 women, mean age $21.5 \pm 1.3$ (standard deviation, SD) years] were selected from 30 randomly selected Japanese college students who visited our pulmonary function laboratory for actual training of pulmonary function testing including methacholine challenge test using partial and full flowvolume curves. Subjects with a history of wheezing were excluded (Table 1). All subjects gave informed consent before entering the study. The Ethics Committee of Kanazawa University Hospital approved the present study.

\section{Study Design}

We measured airway responsiveness to methacholine using partial and full flow-volume curves in 28 normal subjects. Study design is shown in Figure 1. Increasing concentrations of methacholine were inhaled until a fall of $20 \%$ or more in $\mathrm{FEV}_{1}\left(\mathrm{PC}_{20}-\mathrm{FEV}_{1}\right)$ from the post-saline value occurred. After each concentration of methacholine inhalation, partial and full flow-volume curves were measured. Coughs were counted for $2 \mathrm{~min}$ during the inhalation and for $30 \mathrm{~min}$ following the inhalation of methacholine at $\mathrm{PC}_{20}-\mathrm{FEV}_{1}$. After cough count, the bronchoconstriction was subsequently reversed with salbutamol.

\section{Methacholine inhalation challenge}

Methacholine chloride was dissolved in physiologic saline to make solutions of $0.04,0.08,0.16,0.31,0.63$, $1.25,2.5,5,10,20,40,80$, and $160 \mathrm{mg} / \mathrm{ml}$. Physiologic saline solution and methacholine were inhaled from a nebulizer (DeVilbiss 646, DeVilbiss Health Care; Somerset, PA) operated by compressed air at $5 \mathrm{l} / \mathrm{min}$. The nebulizer output was $0.28 \mathrm{ml} / 2 \mathrm{~min}$. Saline solution was inhaled first for $2 \mathrm{~min}$ and partial and full flow volume curves were measured using a computerized spirometer

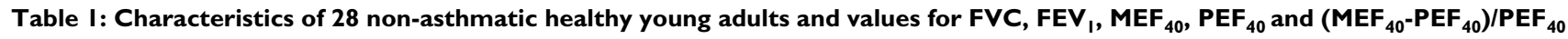
ratio at baseline

\begin{tabular}{|c|c|}
\hline Gender: & 2 men and 26 women \\
\hline Age: & $21.5 \pm 1.3$ years old \\
\hline Height: & $159.9 \pm 5.5 \mathrm{~cm}$ \\
\hline Weight: & $51.0 \pm 5.6 \mathrm{~kg}$ \\
\hline FVC: & $3.46 \pm 0.72 \mathrm{~L}(107.4 \pm 13.4 \%$ of predicted value $)$ \\
\hline $\mathrm{FEV}_{1}$ : & $3.20 \pm 0.62 \mathrm{~L}(97.7 \pm$ I I.7\% of predicted value $)$ \\
\hline $\mathrm{FEV}_{1} / \mathrm{FVC}$ ratio: & $92.7 \pm 4.2 \%$ \\
\hline $\mathrm{MEF}_{40}:$ & $3.56 \pm 0.72 \mathrm{~L} / \mathrm{s}$ \\
\hline $\mathrm{PEF}_{40}$ : & $3.4 \mathrm{I} \pm 0.82 \mathrm{~L} / \mathrm{s}$ \\
\hline$\left(\mathrm{MEF}_{40}-\mathrm{PEF}_{40}\right) / \mathrm{PEF}_{40}$ ratio: & $0.074 \pm 0.22$ \\
\hline
\end{tabular}




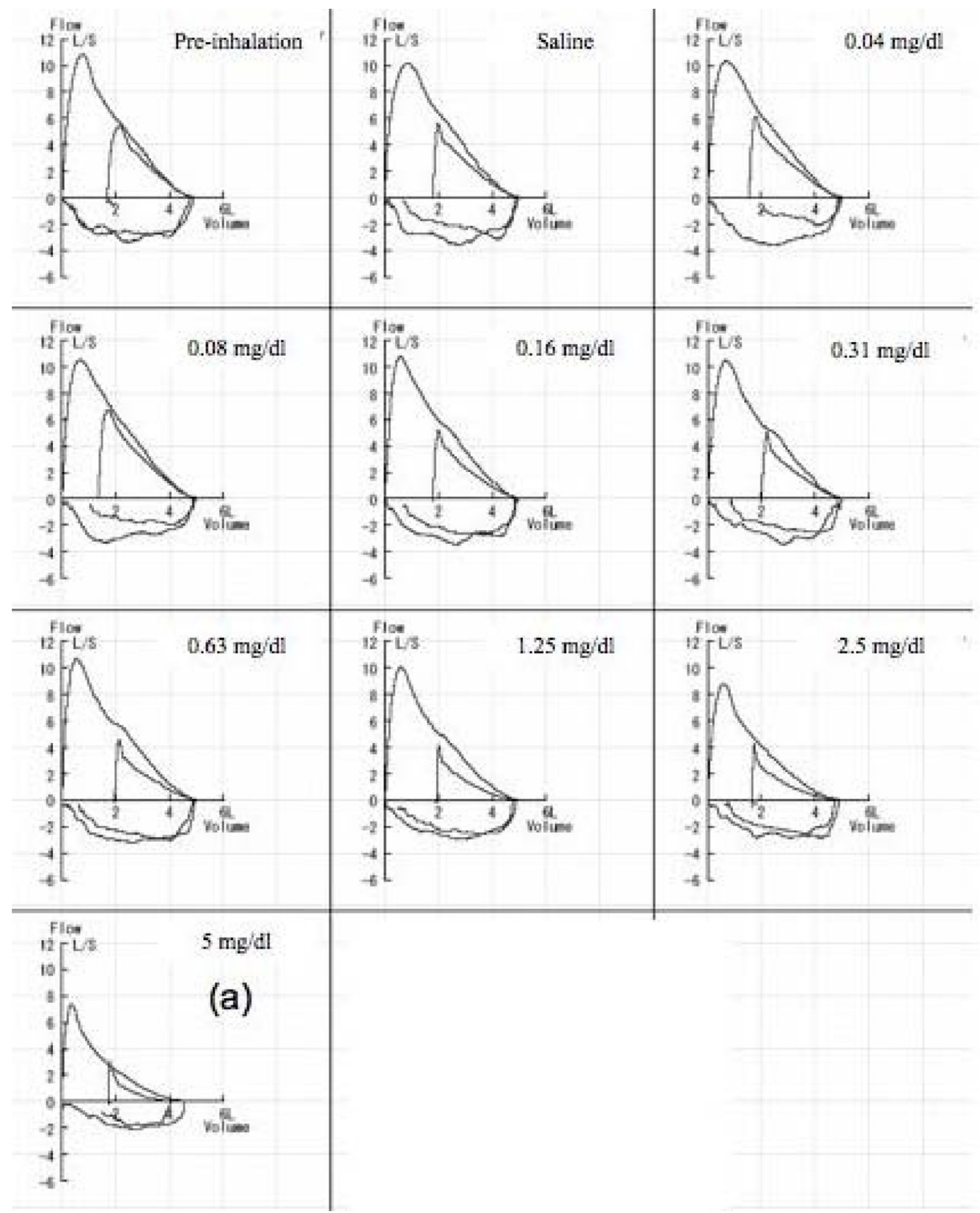

\section{Figure I}

Study design is shown with an example. Increasing concentrations of methacholine $(0.04,0.08,0.16,0.31,0.63,1.25,2.5$, $5,10,20,40,80$, and $160 \mathrm{mg} / \mathrm{ml})$ were inhaled until a fall of $20 \%$ or more in $F E V_{1}\left(P_{20}-F E V_{1}\right)$ from the post-saline value occurred. After each concentration of methacholine inhalation, partial and full flow-volume curves were measured. Coughs were counted for 2 min during the inhalation and for 30 min following the inhalation of methacholine at $P C_{20}-F^{-} V_{1}$. [(a) In this case]. 
(CHESTAC-9800; CHEST; Tokyo, Japan). After confirming that the change in $\mathrm{FEV}_{1}$ from the baseline value after inhalation of saline solution was $10 \%$ or less, inhalation of methacholine was started. Methacholine was inhaled for 2 min by tidal mouth breathing wearing a nose clip, and this was followed immediately by 3 measurements of partial and full flow-volume curves at $1 \mathrm{~min}$ intervals and the curve with the largest forced vital capacity (FVC) was retained for analysis. Subjects avoided to deep inspiration (DI) before the each measurements of partial and full flow-volume curves. Increasing concentrations of methacholine were inhaled until $\mathrm{PC}_{20}-\mathrm{FEV}_{1}$.

\section{Partial and full flow-volume curves}

Partial and full flow-volume curves were measured by the modified method of Fish and co-workers [15]. Flow-volume curve maneuvers were performed in the following manner. After a period of normal tidal breathing subjects momentarily held their breath at slightly above the endtidal inspiration (approx 60\% of FVC) and then forcibly expired to residual volume (RV) level. After reaching the RV level, subjects inspired to total lung capacity (TLC) level as rapidly as possible (this is deep inspiration.) and then immediately performed forced expiration. The expiratory flow at $40 \%$ above RV level from the full forced vital capacity $\left(\mathrm{MEF}_{40}\right)$ was obtained and the volume level was used as the reference volume level to determine the isovolume flow from the partial curve $\left(\mathrm{PEF}_{40}\right)$. The levels of end- tidal inspirations were similarly adjusted in all partial flow-volume curves. (Figure 1)

The bronchodilating effect of DI on methacholine induced-bronchoconstriction was expressed as the ratio of $\left(\mathrm{MEF}_{40}-\mathrm{PEF}_{40}\right) / \mathrm{PEF}_{40}$ [16] (Figure 2). Especially, the ratio of $\left(\mathrm{MEF}_{40}-\mathrm{PEF}_{40}\right) / \mathrm{PEF}_{40}$ after the inhalation of $\mathrm{PC}_{20}-\mathrm{FEV}_{1}$ concentration of methacholine was defined as DI index. DI index means bronchodilating effect of deep inspiration following measurements of partial flow-volume curves on $\mathrm{PC}_{20}-\mathrm{FEV}_{1}$ concentration of methacholine-induced bronchoconstoriction.

\section{Data analysis}

Values of $\mathrm{PC}_{20}-\mathrm{FEV}_{1}$, concentration of methacholine which produced $35 \%$ or more fall in $\mathrm{MEF}_{40}\left(\mathrm{PC}_{35}-\mathrm{MEF}_{40}\right)$ and $\mathrm{PEF}_{40}\left(\mathrm{PC}_{35}-\mathrm{PEF}_{40}\right)$ were expressed as geometric means with the geometric standard error of the mean (GSEM) expressed as a factor. Values for FVC, $\mathrm{FEV}_{1}$, $\mathrm{MEF}_{40}$, and $\mathrm{PEF}_{40}$ were reported as arithmetic means and standard deviations of the mean (SD). Wilcoxon signedranks test was applied to assess the change in the ratio of $\left(\mathrm{MEF}_{40}-\mathrm{PEF}_{40}\right) / \mathrm{PEF}_{40}$. We constructed simple regression models to evaluate the relationship between any pairs of the number of coughs for $32 \mathrm{~min}$ during and following the inhalation of $\mathrm{PC}_{20}-\mathrm{FEV}_{1}$ concentration of methacholine, DI index, concentration of inhaled methacholine and changes in $\mathrm{FEV}_{1}$ and $\mathrm{PEF}_{40}$ by the methacholine inha- a

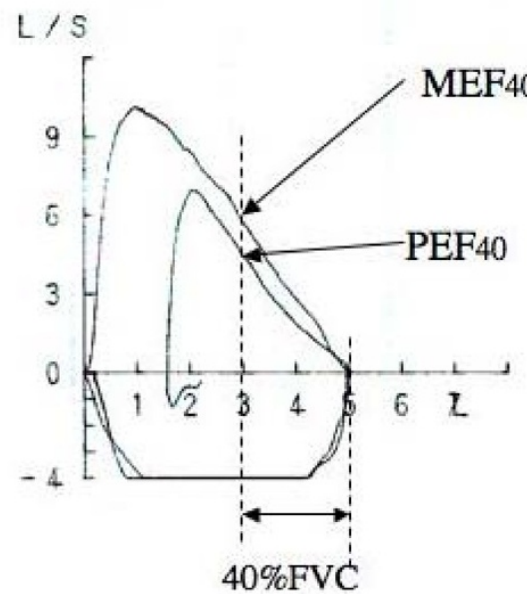

b

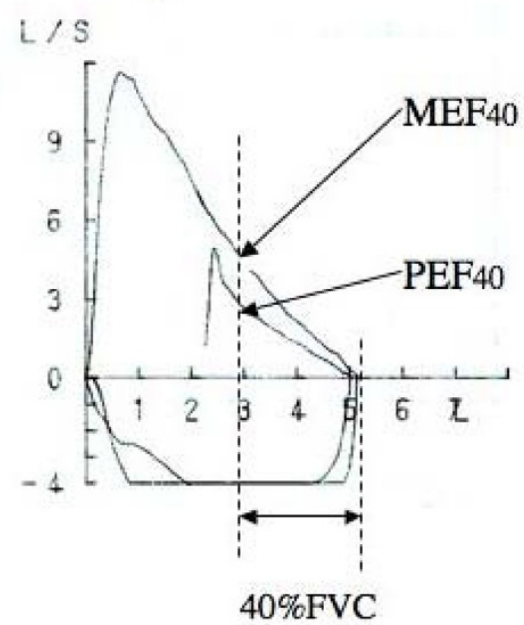

\section{Figure 2}

Examples of partial and full expiratory flow-volume curves before (a) and after (b) inhalation of methacholine in a young woman. Partial curves were performed from end-tidal inspiration; upon reaching residual volume level, subjects

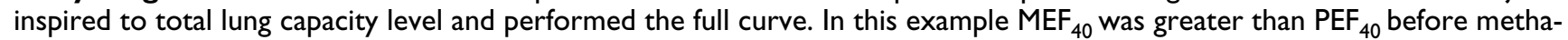
choline inhalation, and the difference became much more after inhalation of $0.5 \mathrm{mg} / \mathrm{ml}$ of methacholine, indicating stronger bronchodilator effect of deep inspiration (DI) on methacholine-induced bronchoconstriction. 
Table 2: Airway responsiveness to methacholine, DI index and number of coughs for $\mathbf{3 2}$ min during and following the inhalationof methacholine

\begin{tabular}{lr}
\hline Airway responsiveness & $71.6(\mathrm{GSEM}, \mathrm{I} .28) \mathrm{mg} / \mathrm{ml}$ \\
PC20-FEVI & $21 . \mathrm{I}(\mathrm{GSEM}, \mathrm{I} .28) \mathrm{mg} / \mathrm{ml}$ \\
PC35-MEF40 & $6.22(\mathrm{GSEM}, \mathrm{I} .27) \mathrm{mg} / \mathrm{ml}$ \\
PC35-PEF40 & $22.0 \pm 9.0 \%$ \\
After inhalation of PC20-FEVI concentration of methacholine & $53.4 \pm 20.8 \%$ \\
Percent decrease in FEVI from the baseline value & $63.0 \pm 18.2 \%$ \\
Percent decrease in MEF40 from the baseline value & $0.41 \pm 0.39$ \\
Percent decrease in PEF40 from the baseline value & $39.3 \pm 29.7 / 32 \mathrm{~min}$ \\
(MEF40-PEF40)/PEF40 ratio (DI index) & \\
Number of coughs & \\
\end{tabular}

lation. In all analyses, values of $\mathrm{p}<0.05$ were considered statistically significant.

\section{Results}

The mean values for FVC, \% predicted value of FVC, $\mathrm{FEV}_{1}$, $\%$ predicted value of $\mathrm{FEV}_{1}, \mathrm{FEV}_{1} / \mathrm{FVC}$ ratio, $\mathrm{MEF}_{40}, \mathrm{PEF}_{40}$, $\left(\mathrm{MEF}_{40}-\mathrm{PEF}_{40}\right) / \mathrm{PEF}_{40}$ are shown in Table 1 . The geometric mean values for $\mathrm{PC}_{20}-\mathrm{FEV}_{1}, \mathrm{PC}_{35}-\mathrm{MEF}_{40}$, and $\mathrm{PC}_{35}-\mathrm{PEF}_{40}$, the mean value for percent change in $\mathrm{FEV}_{1}, \mathrm{MEF}_{40}$, and $\mathrm{PEF}_{40}$ from the baseline value, DI index and the number of coughs for $32 \mathrm{~min}$ during and following the inhalation of $\mathrm{PC}_{20}-\mathrm{FEV}_{1}$ concentration of methacholine are shown in Table 2. In $9(32.1 \%)$ of 28 normal subjects, $20 \%$ or more fall in $\mathrm{FEV}_{1}$ did not occur at the final concentration of methacholine solution $(160 \mathrm{mg} / \mathrm{ml})$, and the $\mathrm{PC}_{20}-\mathrm{FEV}_{1}$ value for these subjects was assumed to be $320 \mathrm{mg} / \mathrm{ml}$ for statistical analysis. $35 \%$ or more fall in $\mathrm{MEF}_{40}$ was not produced by the final concentration of methacholine in 4 (14.2\%) of 28 subjects and the $\mathrm{PC}_{35}-\mathrm{MEF}_{40}$ value for these subjects was assumed to be $320 \mathrm{mg} / \mathrm{ml}$ for statistical analysis. On the other hand, $35 \%$ or more fall in $\mathrm{PEF}_{40}$ was produced by $160 \mathrm{mg} / \mathrm{ml}$ or less of methacholine in all subjects.

The mean value for the ratio of $\left(\mathrm{MEF}_{40}-\mathrm{PEF}_{40}\right) / \mathrm{PEF}_{40}$ following inhalation of methacholine at individual concentration causing $20 \%$ or more fall in $\mathrm{FEV}_{1}$ (DI index) was significantly increased from the baseline value. $(0.41 \pm$ 0.39 from $0.074 \pm 0.22, \mathrm{p}=0.003$ ) [Figure 3].

The number of coughs for 32 min during and following the inhalation of $\mathrm{PC}_{20}-\mathrm{FEV}_{1}$ concentration of methacholine was $39.3 \pm 29.7 / 32 \mathrm{~min}$. As shown in Figure 4, the number of coughs during and following the inhalation was significantly correlated with DI index $(\mathrm{r}=0.57, \mathrm{p}=$ $0.0015)$, but not with $\mathrm{PC}_{20}-\mathrm{FEV}_{1}$ concentration of methacholine $(\mathrm{r}=0.22, \mathrm{p}=0.26)$, or change in $\mathrm{FEV}_{1}(\mathrm{r}=0.30$, $\mathrm{p}$ $=0.12)$ or $\operatorname{PEF}_{40}(\mathrm{r}=0.31, \mathrm{p}=0.11)$ by inhalation of the $\mathrm{PC}_{20}-\mathrm{FEV}_{1}$ concentration of methacholine.

\section{Discussion}

In this study, we measured airway responsiveness to methacholine using partial and full flow-volume curves and coughs caused by the inhalation of $\mathrm{PC}_{20}-\mathrm{FEV}_{1}$ concentration of methacholine in 28 normal subjects. The bronchodilating effect of DI on methacholine inducedbronchoconstriction was evaluated using the ratio of $\left(\mathrm{MEF}_{40}-\mathrm{PEF}_{40}\right) / \mathrm{PEF}_{40}$. We found that methacholineinduced cough was associated with the bronchodilating effect of DI on methacholine induced-bronchoconstriction, but not with $\mathrm{PC}_{20}-\mathrm{FEV}_{1}$ concentration of inhaled methacholine or the provocation-induced decrease in $\mathrm{FEV}_{1}$ in normal subjects. We, therefore, suggest that cough triggered by bronchoconstriction is regulated by protective response against bronchoconstriction, but not by the magnitude of bronchoconstriction. Canning et al. [17]

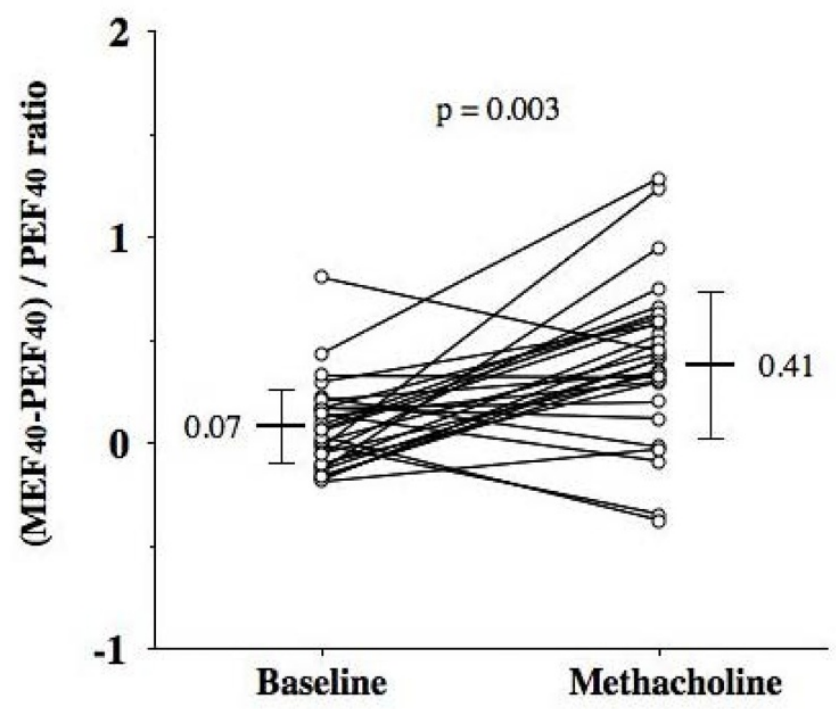

Figure 3

Deep inspiration (DI) effect on bronchomotor tone before and after inhalation of methacholine at individual concentration causing $\mathbf{2 0} \%$ or more fall in FEV . $\left(\mathrm{MEF}_{40}-\mathrm{PEF}_{40}\right) / \mathrm{PEF}_{40}$ ratio was calculated as an index of $\mathrm{DI}$ effect on bronchomotor tone. 


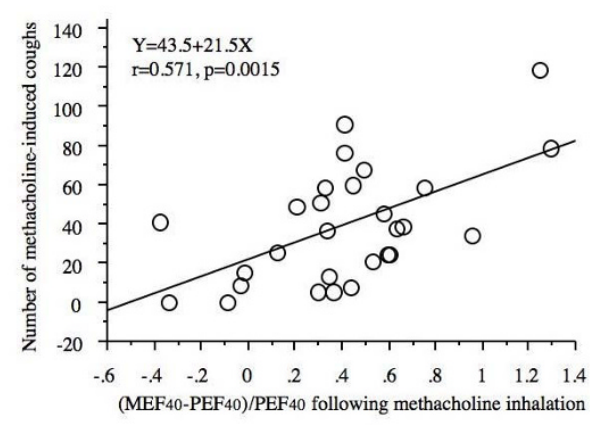

A

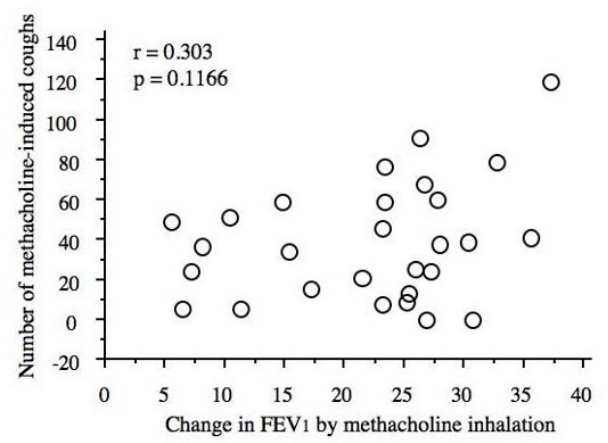

C

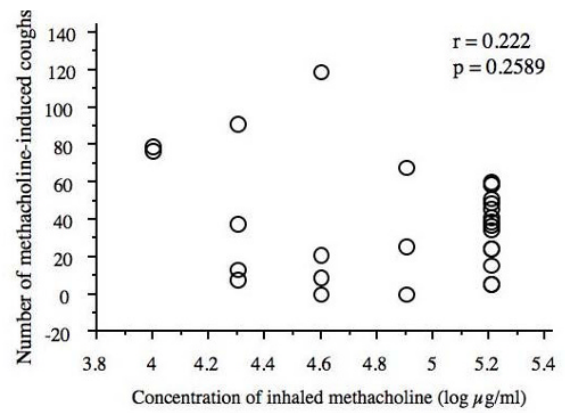

B

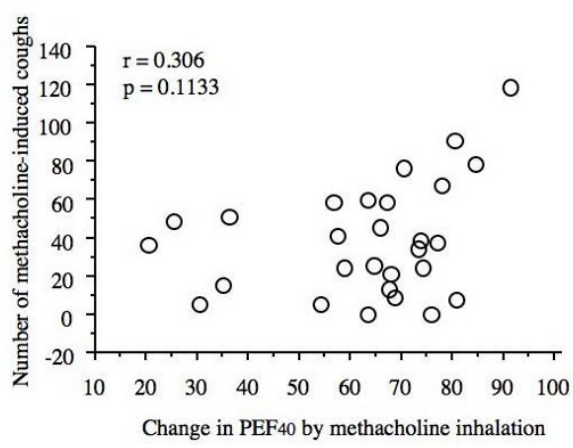

D

\section{Figure 4}

Correlation of number of methacholine-induced cough with deep inspiration (DI) effect on methacholineinduced bronchoconstriction (a), concentration of inhaled methacholine (b), intensity of methacholineinduced bronchoconstriction assessed by FEVI (c) and intensity of methacholine-induced bronchoconstriction assessed by PEF40 (d). Concentration of methacholine in this case means the concentration causing $20 \%$ or more fall in $\mathrm{FEV}_{\mathrm{I}}$ in individual subjects.

reported in anesthetized guinea pigs that the administration of methacholine via the pulmonary artery caused bronchoconstriction and vigorously activated rapidly adapting receptors.

DI can affect acute airway narrowing by following two mechanisms: bronchoprotection and bronchodilation. Scichilone and coworkers [18] studied on bronchoprotection and bronchodilation in normal subjects. Wan and coworkers [19] studied on these mechanisms in an in vivo preparation of guinea pig airway smooth muscle (ASM). Bronchoprotection was defined in these studies as the reduction in bronchoconstriction resulting from act of DI before the ASM has been stimulated to constrict [19] and bronchodilation as the reduction in bronchoconstriction after ASM activation by spasmogen. Scichilone and coworkers reported that the bronchoprotective effects of DI were stronger than the bronchodilating effects and also that bronchoprotection was absent in asthmatics $[18,20]$. The effect of stretch on ASM preparations was found to be consistent with the change observed in in vivo studies [19], which suggests that the effects of DI on airway narrowing are indeed mediated by its action on ASM.

It has been shown that in asthmatics there is impaired dilatation of the airways in response to stretch $[15,21]$. This is based on the differences in the response of asthmatic subjects to DI compared with normal subjects. Fish and associates [15] measured changes in airway conductance and partial flow-volume curves in response to methacholine inhalation in asthmatics and patients with allergic rhinitis before and after DI. Although asthmatics showed greater airway narrowing as assessed by either measurement, the difference between asthmatic and rhinitis patients was much less prior to than after DI. They suggested that failure of bronchodilating effect of DI was an important cause of airway hyperresponsiveness in asthma.

In this study, the number of coughs following methacholine inhalation was not correlated with concentration of inhaled methacholine causing a $20 \%$ or more fall in 
$\mathrm{FEV}_{1}$, or the methacholine-induced change in $\mathrm{FEV}_{1}$ or $\mathrm{PEF}_{40}$. Irwin and coworkers [22] studied to determine whether any features of positive results of methacholine inhalation challenge or the results of a one-week trial of inhaled beta-agonist therapy were helpful in determining whether the cough was due to asthma. They concluded that the results of airway responsiveness to methacholine could not predict the response of cough to asthma therapy. These results suggest that severity of cough due to bronchoconstriction does not necessarily consist with BHR. It seems to be clinically important for the treatment strategy of chronic cough [23] to distinguish between cough caused by cough reflex hypersensitivity and cough triggered by bronchoconstriction, because the former doesn't react to the bronchodilator at all, and the latter reacts to the bronchodilator. It is also possible that the mechanism of cough is complex, with contributions from airway inflammation, a heightened cough reflex, and bronchoconstriction.

In conclusion, this is the report concerning cough triggered by methacholine-induced bronchoconstriction in humans. We found that bronchoconstriction-triggered cough was associated with the bronchodilating effect of DI on the induced-bronchoconstriction, but not with $\mathrm{PC}_{20}-\mathrm{FEV}_{1}$ concentration of inhaled methacholine or methacholine-induced decrease in $\mathrm{FEV}_{1}$ in normal subjects. Further studies are needed to investigate the relationship among cough triggered by methacholineinduced bronchoconstriction, ASM tone and bronchodilating effect of DI on the methacholine-induced bronchoconstriction in patients with CVA in comparison with typical asthma, atopic cough and so on.

\section{Conflict of interests Statement}

The authors declare that they have no competing interests.

\section{Authors' contributions}

NO recruited the subjects, performed the data collecting and draft the manuscript. MF conceived the study, contributed to its design, data acquisition, data interpretation, and review and correction of the manuscript. AT performed the statistical analysis and data interpretation. $\mathrm{JH}$ participated in data acquisition. AH participated in data acquisition. MN participated in data acquisition. MA contributed to data interpretation. NK contributed to data interpretation. All authors have given final approval of the version to be published.

\section{Acknowledgements}

This study was supported in part by a grant-in-aid for Scientific Research from the Ministry of Education, Culture, Sports Science and Technology Japan (I 7607003).

\section{References}

I. Corrao WM, Braman SS, Irwin RS: Chronic cough as the sole presenting manifestation of bronchial asthma. The New England journal of medicine 1979, 300:633-637.

2. Brightling CE, Ward R, Goh KL, Wardlaw AJ, Pavord ID: Eosinophilic bronchitis is an important cause of chronic cough. American journal of respiratory and critical care medicine 1999, 160:406-4I0.

3. Fujimura M, Ogawa $\mathrm{H}$, Nishizawa $\mathrm{Y}$, Nishi K: Comparison of atopic cough with cough variant asthma: Is atopic cough a precursor of asthma? Thorax 2003, 58: |4-18.

4. Irwin RS, French CL, Curley FJ, Zawacki JK, Bennett FM: Chronic cough due to gastroesophageal reflux. Clinical, diagnostic, and pathogenetic aspects. Chest 1993, 104:151 I-I5I7.

5. Ebihara T, Sekizawa K, Ohrui T, Nakazawa H, Sasaki H: Angiotensin-converting enzyme inhibitor and danazol increase sensitivity of cough reflex in female guinea pigs. American journal of respiratory and critical care medicine 1996, I53:812-8I9.

6. Fujimura M, Kamio $\mathrm{Y}$, Hashimoto T, Matsuda T: Cough receptor sensitivity and bronchial responsiveness in patients with only chronic nonproductive cough: In view of effect of bronchodilator therapy. J Asthma 1994, 3 I:463-472.

7. Dicpinigaitis PV, Alva RV: Safety of capsaicin cough challenge testing. Chest 2005, I 28: 196-202.

8. Jia Y, McLeod RL, Wang X, Parra LE, Egan RW, Hey JA: Anandamide induces cough in conscious guinea-pigs through vrl receptors. Br J Pharmacol 2002, I37:831-836.

9. Groneberg DA, Niimi A, Dinh QT, Cosio B, Hew M, Fischer A, Chung KF: Increased expression of transient receptor potentialvanilloid- I in airway nerves of chronic cough. Am J Respir Crit Care Med 2004, I 70: 1276-1280.

10. Ternesten-Hasseus E, Farbrot A, Lowhagen O, Millqvist E: Sensitivity to methacholine and capsaicin in patients with unclear respiratory symptoms. Allergy 2002, 57:50 I-507.

II. Fujimura M, Sakamoto S, Kamio Y, Matsuda T: Cough receptor sensitivity and bronchial responsiveness in normal and asthmatic subjects. Eur Respir J 1992, 5:291-295.

12. Koskela HO, Martens R, Brannan JD, Anderson SD, Leuppi J, Chan $\mathrm{HK}$ : Dissociation in the effect of nedocromil on mannitolinducedcough or bronchoconstriction in asthmatic subjects. Respirology (Carlton, Vic) 2005, 10:442-448.

13. Hargreave FE, Dolovich J, O'Byrne PM, Ramsdale EH, Daniel EE: The origin of airway hyperresponsiveness. J Allergy Clin Immunol 1986, 78:825-832.

14. Chausow AM, Banner AS: Comparison of the tussive effects of histamine and methacholine in humans. Journal of applied physiology: respiratory, environmental and exercise physiology 1983, 55:54l-546.

15. Fish JE, Ankin MG, Kelly JF, Peterman VI: Regulation of bronchomotor tone by lung inflation in asthmatic and nonasthmatic subjects. Journal of applied physiology: respiratory, environmental and exercise physiology 1981, 50:1079-1086.

16. Fujimura M, Nomura M, Sakamoto S, Kamio Y, Shibata K, Ogawa H, Nishi K, Matsuda T: [effect of deep inspiration on maximum expiratory flow (vmax) depends on basal bronchomotor tone in young healthy females]. Nihon Kyobu Shikkan Gakkai Zasshi 1990, 28: 105-II2.

17. Canning BJ, Mazzone SB, Meeker SN, Mori N, Reynolds SM, Undem $B$ J: Identification of the tracheal and laryngeal afferent neurones mediating cough in anaesthetized guinea-pigs. The Journal of physiology 2004, 557:543-558.

18. Scichilone N, Kapsali T, Permutt S, Togias A: Deep inspirationinduced bronchoprotection is stronger than bronchodilation. Am J Respir Crit Care Med 2000, 162:910-916.

19. Wang L, Chitano P, Murphy TM: Length oscillation induces force potentiation in infant guinea pig airway smooth muscle. Am J Physiol Lung Cell Mol Physiol 2005, 289:L909-9I5.

20. Kapsali T, Permutt S, Laube B, Scichilone N, Togias A: Potent bronchoprotective effect of deep inspiration and its absence in asthma. Journal of applied physiology: respiratory, environmental and exercise physiology 2000, 89:7 I I-720.

21. King GG, Moore BJ, Seow CY, Pare PD: Time course of increased airway narrowing caused by inhibition of deep inspiration during methacholine challenge. Am J Respir Crit Care Med 1999, 160:454-457. 
22. Irwin RS, French CT, Smyrnios NA, Curley FJ: Interpretation of positive results of a methacholine inhalation challenge and I week of inhaled bronchodilator use in diagnosing and treating cough-variant asthma. Arch Intern Med 1997, 157:198I-I 987.

23. Kohno S, Ishida T, Uchida $Y$, Kishimoto H, Sasaki H, Shioya T, Tokuyama K, Niimi A, Nishi K, Fujimura M, et al:: The japanese respiratory society guidelines for management of cough. Respirology (Carlton, Vic) 2006, I I (Suppl 4):SI 35- I86.

Publish with Bio Med Central and every scientist can read your work free of charge

"BioMed Central will be the most significant development for disseminating the results of biomedical research in our lifetime." Sir Paul Nurse, Cancer Research UK

Your research papers will be:

- available free of charge to the entire biomedical community

- peer reviewed and published immediately upon acceptance

- cited in PubMed and archived on PubMed Central

- yours - you keep the copyright

Submit your manuscript here:

http://www.biomedcentral.com/info/publishing_adv.asp 